This item was submitted to Loughborough's Research Repository by the author.

Items in Figshare are protected by copyright, with all rights reserved, unless otherwise indicated.

\title{
Xi Jin-Ping's world cup dreams: from a major sports country to a world sports power
}

PLEASE CITE THE PUBLISHED VERSION

http://dx.doi.org/10.1080/09523367.2016.1243103

\section{PUBLISHER}

(C) Taylor \& Francis

\section{VERSION}

AM (Accepted Manuscript)

\section{PUBLISHER STATEMENT}

This work is made available according to the conditions of the Creative Commons Attribution-NonCommercialNoDerivatives 4.0 International (CC BY-NC-ND 4.0) licence. Full details of this licence are available at: https://creativecommons.org/licenses/by-nc-nd/4.0/

\section{LICENCE}

CC BY-NC-ND 4.0

\section{REPOSITORY RECORD}

Tan, Tien-Chin, Hsien Che Huang, Alan Bairner, and Yu-Wen Chen. 2019. "Xi Jin-ping's World Cup Dreams: From a Major Sports Country to a World Sports Power". figshare. https://hdl.handle.net/2134/22982. 


\title{
Xi Jin-Ping's World Cup Dreams: from a Major Sports Country to a World Sports Power
}

\begin{abstract}
Football is among the world's most popular sports. It is also one which China has sought to develop in the field of global professional sport. Nevertheless, the professionalization of football in China has not to date actually improved China's Olympic achievement in the sport. In stark contrast to the glory of being the country that won most gold medals at the 2008 Olympics, China's poor football performance has been troublesome for the country's leader. In 2009, newly elected Xi Jin-Ping made a public statement about promoting elite football and expressed his personal hope that China would be capable of both qualifying for the final stages and winning the FIFA World Cup. With such concern on the part of the state leader, attention turned to football, with many private enterprises beginning to echo government policy by demonstrating a willingness to promote elite football. In addition, to accelerate football development, the Chinese government promised to take action on the separation of government and football associations. Research on this process was based on the theoretical framework of state corporatism derived from the work of Schmitter (1974). Semi-structured interviews were conducted as the method of data collection aimed at helping us understand how Chinese government either integrated or controlled relevant stakeholders such as NGOs and private enterprises, and further, to discuss the interactions between them.
\end{abstract}

Key words: China, Corporatism, Elite Football, Policy Learning, Sports Power

\section{Introduction}

Football is one of the most popular sports in the world. It was also the first sport to be professionalized in China. Nevertheless, the professionalization of football has not brought about a marked improvement in the standard of China's elite football. Compared with China's prominent achievement of winning most gold medals with 51 (100 in total) at the 2008 Olympic Games in Beijing, the outcome of its investment in elite football seemed to have brought shame to the then president of the People's Republic China (PRC), Hu Jin-Tao. As a result, after the 2008 Olympics, Hu demanded further actions in order to fulfill China's sports policy goal of going "from a major sports country to a world sports power". Moreover, during an official visit to Germany in 2009, Xi Jin-Ping, the then-vice president and now the current president of the PRC, also expressed the country's determination to put considerable effort into China's elite football development. At an official meeting with the president of the Korea Democratic Party in 2011, Xi had highlighted his three World Cup dreams of "participating in the World Cup", "hosting the World Cup", and "being the World Cup champions". In light of China's leaders' concerns about the future of the country's elite football, the once neglected "campus football” has attracted 
increasing attention in the wider society. Private corporations have echoed the national leaders' proclamations by starting to support the development of elite football in China. Meanwhile, the government promised to speed up the reform of the football administration system in China so as to promote elite football. This research aims to investigate China's strategies for its elite football development after the 2008 Beijing Olympics and to understand the power relations and interactions among the stakeholders in Chinese elite football.

\section{Analytical Framework and Methodological Issues}

According to Schmitter and Lehmbruch, corporatism is "a system of interest representation in which the constituents are organized into a limited number of singular, compulsory, non-competitive, hierarchically ordered and functionally differentiated categories, recognized or licensed (if not created) by the state and granted a deliberate representational monopoly within their respective categories in exchange for observing certain controls on their selection of leaders and articulation of demands and supports."1 Corporatism has been traditionally associated with authoritarianism, and often adopted to help explain the political and economic development of Portugal, Spain, Italy and various countries in Latin America with an emphasis on the controlling influence of the state on political economy. ${ }^{2}$ However, as well as in authoritarian societies corporatism can be found in countries with different political, economic and cultural conditions such as Sweden, Switzerland, Holland and other social democratic countries. In order to expand on its role, Schmitter divided corporatism into two categories: national corporatism and societal corporatism. ${ }^{3}$ Based on the extent of governmental power over the country, societal corporatism was thus separated from the corporatism that had previously been linked to authoritarianism, thereby highlighting two types of relationship between governments and interest groups: interest group-dominated nations or nation-dominated interest groups. ${ }^{4}$ Unlike traditional corporatism that was centered on the idea of authoritarianism, the formation of societal corporatism starts with the coming together of various groups of people with similar interests, each of which comes up with its representative to take part in the policy-making process of the country. This kind of corporatism is commonly found in socially democratic countries. Sweden, Demark, Norway, Holland and other democratic European countries as such are examples based on societal corporatism. ${ }^{5}$ However, China's dominant-party system and its communist-based society means a political and economic social context that is very different from this idea of societal corporatism.

Viewed from the perspective of the model of state corporatism, the interactions between government and society are led by government. As the policy maker, the government tends to mediate between interest groups with specific aims. Indeed, the formation of interest groups in society is frequently manipulated by government and interest groups are commissioned by, as well as subordinated to, government for the propagation of its policies. According to Schmitter ${ }^{6}$, based on the model of state corporatism, governments have their own objectives when it comes to cooperation with interest groups, in particular the maintenance of authority over the nation. 
Governments will establish an interest group mediator according to policy needs, as well as including all relevant members within the system of governance. The commissioned interest mediator, therefore, possesses a government-granted monopoly, and can thus achieve national objectives through mandatory social cooperation. State corporatism of this type can frequently be found in authoritarian states and/or developing countries. Moreover, even when putting aside early studies focused on authoritarian states, there are still many discussions within academia today about the contemporary authoritarian-oriented countries, including Singapore, South Korea, Japan, and Taiwan, at least between the 1950s and 1980s. The perspective of state corporatism is used to discuss the interactions between governments and interest groups in such countries ${ }^{7}$. Not surprisingly, therefore, the approach is also frequently adopted to analyze the prevailing circumstances in China ${ }^{8}$. Describing the interactions between the Chinese government and private corporations, Solinger ${ }^{9}$ pointed out that the state has gradually untied society following economic reform. The government and corporations are now more inter-dependent, thereby blurring the boundary between state and society. Nevertheless, the main resources are still controlled by the state. The private corporations are required to establish a good relationship with government if they are to gain access to resources. As Chinese scholars Liu ${ }^{10}$ and Sun ${ }^{11}$ have claimed, the relationship between the government and social groups, as well as the process of the transforming governance in China, both remain within the framework of state corporatism. Therefore, the focus of this study is to identify whether the Chinese government has a specific policy or objective for elite football development as a means by which to enhance understanding of the role played by the Chinese government in this process. Put simply, is the government a passive arbitrator or a purposive dominator. Secondly, if the Chinese government has specific goals for football development, what are the channels to achieve these goals? Does the Chinese government have the power to lead society in this respect? Does society have leverage to negotiate with government? Can these inquiries help us focus on the concept of state corporatism and observe whether society take orders from government during these interactions? Or, have corporate forces gained their momentum such that the development of elite football in China is being operated differently?

With the concept of state corporatism in mind, this analysis draws upon an interrogation of empirical data from interviews conducted with 25 officials involved in various organizational roles within China's administrative system for elite football. Interviews were conducted with officials from organizations that included: the General Administration of Sport (GAS); the Chinese Football Association (CFA); the China Football Association Super League Company (CSLC); the Executive Bureau of CSL; CSL Club managers; Local football management centers. In addition, 8 interviews were conducted with Chinese sports academics and journalists working in China and elsewhere. It was also possible for us to access high ranking sport leaders’ personal accounts from documents and articles for example: i) official websites, such as those of State Council (SC), Ministry of Education (MOE), Ministry of Finance (MOF), GAS, Chinese Olympic Committee (COC), CFA, and; ii) databases, such as SPORTINFO.NET.CN and the China National Knowledge Infrastructure (CNKI); 
and iii) newspapers including China Sport News, Sina Sport News, Titan Sport News, Sohu Sport News, People's Daily Online and Xinhuanet News.

\section{China's Strategies for Elite Football Development after the 2008 Beijing Olympics}

The goal of elite football achievement for China has hit the rock bottom following 2008 Beijing Olympics. The male national football team was knocked out in the World Cup Asian preliminary contests in 2006, 2010, and 2014 consecutively. By July 2009, the Chinese football team's ranking had reached a record low point $\left(108^{\text {th }}\right.$ worldwide and $13^{\text {th }}$ in Asia) according to the Fédération Internationale de Football Association (FIFA). Moreover, on June $15^{\text {th }}$ 2013, the Chinese national team was beaten 1-5 by Thailand in a friendly match, a result that was mocked by the media and by fans as the "615 Massacre". It had been one of the most humiliating days in the history of Chinese football and in order to prevent the further decline of Chinese elite football, several policies were proposed, aimed at halting the decline and gradually fulfilling the three World Cup dreams announced by the new leader, Xi Jing-Ping.

\section{Establishment of "The Control, Ethics and Disciplinary Committee of National Football Leagues (CEDCNFL)”}

According to the vice director of the Sports Ethics and Integrity Risk Research Center, Beijing Sports University, the Chinese Football Association Super League (CSL) has been struggling with issues of match-fixing, gambling, and gang manipulation since its formation. Although the Chinese Football Association (CFA) and Ministry of Public Security (MPS) co-founded a task force for "anti-football gambling activities" in 2006, the outcomes were unsatisfactory. Furthermore, the scandal of high-level officials in the CFA collectively taking bribes was also exposed. In order to stop such deviant activities as match-fixing, gambling, and gang manipulation of football, seven departments in the State Council co-founded the CEDCNFL under the direction of the then vice president, Xi Jing-Ping, after 2008 Beijing Olympics ${ }^{12}$. This move was in accordance with the idea proposed by the executive vice-chairperson of the CFA, Chang Jian, in his 2014 CFA Work Report. CEDCNFL is led by GAS and composed of MPS, the Ministry of Civil Affairs (MCA), the Ministry of Justice (MJ), the People's Bank of China (PBC), State Administration of Taxation (SAT), and State Administration for Industry and Commerce $(\mathrm{SAIC})^{13}$.

\section{Instructions to entrepreneurs to fund CFA}

The then vice president, Xi, highly values the development of Chinese football. Therefore the then state councilor, Liu Yen-dong, assembled and hosted a conference for football reinvigoration on January $28^{\text {th }}$, 2011. The president of Dalian Wanda Group (DWG), Wang Jian-Lin, was invited as the representative of the Chinese corporations. Liu suggested that the Chinese corporations 
should devote more effort to the development of football in China and this received a positive response from Wang who then carried out his promise to supporting Chinese football six months later. On July $3^{\text {rd }}$, 2011, both the initiation of "European Training Camp for Chinese Football Stars of Hope" and the contract signing ceremony for "Strategic Partnership between the CFA and the DWG” took place in the Beijing Institute of Technology (BIT). DWG provided 500 million RMB over three years to fully support the reinvigoration of the Chinese football. One of the senior staff members in charge of the financial affairs of the CFA stated, with reference to the 500 million strategic partnership between DWG and CFA, that it would consist of six elements - selecting youths under 16 for training at top European football clubs, financing three national youth football leagues with athletes aged from 10 to 17, introducing world class foreign head coaches to lead the national team without a salary cap, becoming the name sponsor for CSL, exploring and reforming the current system of assessment and rewarding for referees, and funding the national women's football team ${ }^{9}$.

In addition to Wang's DWG, the board chairperson of Evergrande Real Estate Group (EREG), Xu Jia-Ying, worked with Real Madrid Football Club (RMFC) in Spain to build the Evergrande Football School (EFS) and planned to spend ten years widening the cultivation of youth football talent. EREG would donate 100 million RMB to the China Foundation for Poverty Alleviation (CFPA) annually for ten years. Part of this donation would be used to finance those talented, yet financially disadvantaged, children so that they could have access to professional football training and coaching. This move is closely related to the preference of President Xi concerning football as well as the instructions of the Chinese Communist Party Politburo Standing Committee $(\mathrm{CCPPSC})^{14}$.

\section{Establishing “The National Youth campus football Leading Group Office (NYLGO)”}

According to a former official in the CFA School Football Office (SFO), SFO was initially co-founded by GAS and the Ministry of Education (MOE), under the instruction of the State Council, to provide training for more than 5,000 principals and instructors as well as 800 level C and D coaches annually. The elite training centers started a trial run in 20 cities in 2014. GAS contributed sports lottery profits and increased investment from 40 million RMB in 2009 to 56 million RMB in $2013^{15}$. In order to gain more resources from the MOE, the responsibility of developing campus football was taken over from GAS to the MOE. ${ }^{16}$ In 2015, the MOE worked with the National Development and Reform Commission (NDRC), the Ministry of Finance (MOF), the State Administration of Press, Publication, Radio, Film, and Television (SAPPRFT), GAS, and the Central Committee of the Communist Young League (CCCYL) to form the "NYLGO" with the consent of the State Council. The MOE director leads the group, while Wang Deng-Feng, the head of the Division of Physical, Health and Arts Education (DPHAE) in the MOE, serves as the office chief; members of this office include officials from the relevant departments mentioned above. ${ }^{17}$ 


\section{Raising the profile and status of football in the National Games}

The GAS director, Liu Peng, made football the focus in his report to the 2011 National Sports Minister Conference for the very first time. In the report he asserted that "the emphases of the Party and the state, the concerns of the political leaders, and the anticipation of the public about the development of football have surpassed the sport itself. We have to acknowledge it is

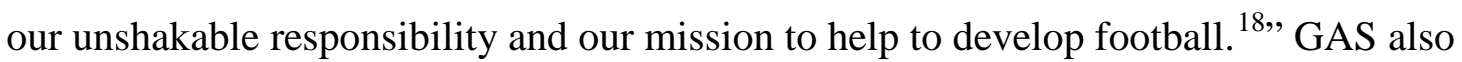
emphasized the significance of football in the National Games because they have become a driving force to motivate local sport bureaus to develop the sport. Specifically, U18 matches were added to the games to sit alongside adult matches. The male and female football teams that had won first place were previously awarded only one medal respectively. However, the scoring system was altered so that a province/city team that secures first place will obtain three gold medals instead of one; this means that the provinces/cities where football has been best developed can now win many as many as six gold medals. This alternation is intended to encourage more local governments to develop the sport ${ }^{19}$. In an interview with Xinhua News Agency, GAS deputy-director, Xiao Tien, suggested that "the provincial governments and the Chinese People's Liberation Army (PLA) value football more since the new policies, such as three gold medals for first place and the addition of U18 matches were introduced. More teams were founded....and if we can persist, the shortage of talent reserves in football may be improved greatly. ${ }^{20,}$

\section{Strengthening the "inviting in" and the "sending out" policy}

The "inviting in and sending out" policy involves government agencies (CFA and MOE) and business stakeholders (Wang from DWG and Xu from EREG). As for “inviting in”, the main purpose is to introduce high-level foreign experts to provide scaled training for Chinese coaches, referees, and instructors. ${ }^{21}$ The CFA executive vice-chairperson, Chang Jian, pointed out in the 2014 CFA Work Report that "systematic and scaled national football training has been available with the support of FIFA and AFC since 2004. For instance, training for professional coaches and instructors was provided together with levels A, B, and C coach training.” Furthermore, Chang Jian also suggested that "level D coach training was made available in 2010 to gradually connect with the world of the professional, levels A, B, C, and D coach training systems. There were also improvements in the training of referees, of referee instructors, and of technical directors." Nonetheless, the MOE also planned to hire 100 quality football coaches to deliver their training services at schools in 40 cities in order to fully promote campus football. During the interview with the XinHua News Agency, the head of DPHAE, MOE, Wang Deng-Feng, suggested that "we would like to ask them to teach football in different schools with football features for one year. Our football coaches will work with and learn from them. They are like the academic advisors in graduate schools. We intend to conduct a one-year trial run to see the outcomes.” He also mentioned that "the MOE planned to invite coaches from countries excelling in football such as 
Germany, Italy, Spain, France, and Argentina. The invitation can be issued either directly by the MOE or from local governments just as the cooperative model between Chengdu and Metz, France that has run for more than a decade. ${ }^{22 \text { ” }}$ This is the first time that the Chinese government has attempted to use the integration of foreign coaches into different schools as one of the "stepping out" strategies.

The "sending out" element refers to encouraging football clubs, corporations, and other social forces to select professional and young players to participate in training in countries excelling in football so as to aspire to play in their high-level professional leagues ${ }^{23}$. Under the direction of the Chinese leaders, in 2011, DWG started to sponsor the Chinese Football Stars of Hope Project. Shi Shue-Ching, the director of football affairs at DWG, said that "the talent training program of the Chinese Football Stars of Hope is one of the crucial items in the strategic partnership between DWG and CFA. The purpose is to cultivate Chinese potential football stars and revitalize Chinese football. The reason why we chose Real Madrid Football Club (RMFC), Valencia Football Club (VFC), and Villarreal CF was not only because they are traditionally top teams in Primera división de Liga but also because they have the leading youth training systems in both Spain and Europe. ${ }^{24}$ ”

\section{Taking action on the separation between the government and football associations}

As for the scandals of CFA officials taking bribes and match-fixing in CSL, during his interview with XinHua News Agency GAS director, Liu Peng, argued, that "CSL needs to be reformed, so as to change the situation that CFA is hosting while managing the games.” He emphasized that "the government-led system of CFA had caused a lot of issues. The unreasonable system was also the hotbed for corruption. Reform is a must and we are initiating specific reforming measures. ${ }^{25}$ " Immediately before the 2014 CFA convention, the GAS deputy-director, Cai Zhen-Hua, invited Wang from DWG and Xu from EREG to serve as the vice-chairpersons for the $10^{\text {th }}$ CFA convention with the expectation of energizing CFA through the power of the corporations ${ }^{26}$. In fact, the formal reform policy was never confirmed until the passing of "The Overall Reform Plan to Boost the Development of Football in China” (the Reform Plan) on the occasion of the $10^{\text {th }}$ assembly of the Central Leading Group for Comprehensively Deepening Reforms hosted by Xi Jing-Ping on February $27^{\text {th }}$, 2015 ${ }^{27}$. After the Reform Plan was announced by the State Council, the GAS deputy-director and the CFA chairperson, Cai Zhen-Hua, pointed out at the press conference that "the Reform Plan has addressed the issue of separation between the government and football associations. The purpose of re-building CFA is clear - to change the overlapping organizational structure of CFA and the Chinese Football Management Center

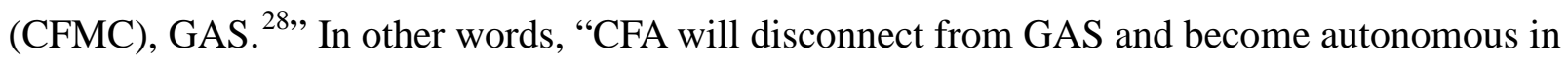
terms of its institutional setup, work planning, financial and salary management, human resources, and professional international communication ${ }^{29}$." However, Cai also stressed that "the disconnection between CFA and GAS does not mean that the government would give up the 


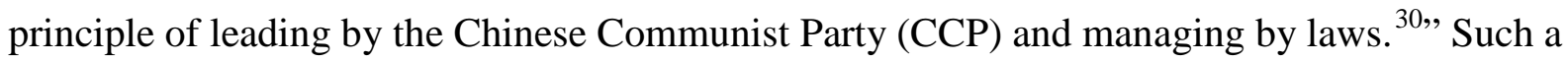
contention came as no surprise because it is specified in the $9^{\text {th }}$ article of the Reform Plan to "enforce leadership by the Party, establish a sound Party structure in association football at all levels, follow the cadre and personnel policies of Party, and reinforce the ideological and political work as well as daily management of cadres. The party committees assigned by CFA will be led by the GAS Party group. ${ }^{31}$ " This revealed that the Party-led principle of the CCP would persist no matter how the reform develops.

\section{Emphasizing the bellwether role of football in the sports industry}

In order to reinforce the link between development of football and industry so as to provide powerful support for football, the State Council of China announced Several Opinions of the State Council of the People's Republic of China, on Accelerating the Development of Sports Industry to Promote the Sport Consumption (The Opinions) on October $20^{\text {th }}$, 2014. In this document, it was emphasized that "football should be viewed as one of the potential industries and be promoted both in depth and width. A long-term development and facility construction plan should be

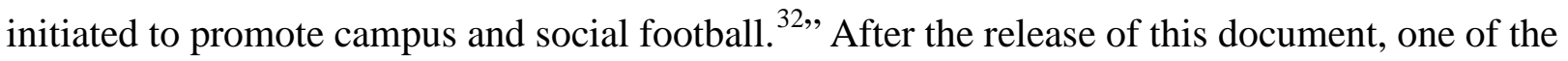
drafters, the GAS vice-director of the commercial affairs department, Chen En-Tang, pointed out the reasons why football was viewed as the entry point for sport industry. He mentioned that "there are a great number of fans of football in China, yet they have been frustrated by the national teams' frequent losses in the international arena. Moreover, the achievements of national

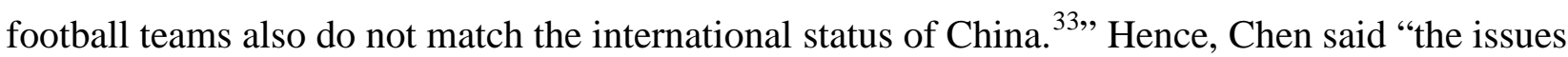
of football have attracted attention from all directions especially the public. Therefore The Opinions specifically proposed mid and long term development programs for football, hoping to actively promote football on campuses and in society. ${ }^{34 \text {, }}$

\section{Power relations and interactions between stakeholders}

Since the 2008 Beijing Olympics, the main stakeholders within the development of Chinese elite football have been government officials and corporate owners. The government officials include president Xi Jing-Ping and corresponding officials from the State Council, the MOE, GAS, NDRC, MOF, CFA, local sport bureaus and football federations, while the most influential corporate owners are Wang from DWG and Chairperson Xu from EREG.

\section{The Pursuit of Xi's Three Dreams for Chinese Elite Football}

The leaders of the People's Republic of China have all been fond of football and made promises to promote the sport. Nonetheless, President Xi was the first and only leader who has made football development one of his major policies and has put continuous efforts towards this. $\mathrm{Xi}$ was on the Hui-Wen football team in high school and liked to watch football matches ${ }^{35}$. His affection for the sport did not end when he became the leader of China. In July 2008, the then vice 
President, $\mathrm{Xi}$, once entered the field of play and made several impressive kicks during a visit to Olympic football stadium and the Chinese female football team in Qinhuangdao. In fact, Xi also showed his well-honed skills on the field while visiting the headquarters of Gaelic Athletic Association in Dublin, Ireland during February, $2012^{36}$. According to Chinese football academia, the then vice President had expressed his dissatisfaction about the under-performing Chinese football team during and after the 2008 Beijing Olympics ${ }^{37}$ and commissioned the State Councilor Liu Yan-Dong to exert his power ${ }^{38}$. Xi mentioned how he had enjoyed football during his visit to Bayer HealthCare in Germany on October $12^{\text {th }}$, 2009. He noted that there were first-class football fans and a considerable market for football in China, yet the competitive level of Chinese football was relatively inferior and he wished the situation could be improved. He announced that "we made a resolution after hosting the 2008 Olympics: it may take long, but we will be determined to develop Chinese football, for we had won gold medals in most other sports. $^{39,}$

After these statements by Xi, Liu Yan-Dong, the councilor of Politburo and State Council, attended a workshop on October $14^{\text {th }}$, 2009. Liu stated publicly that "raising the profile of the Chinese football is significant for constructing an overall world sports power, boosting the healthy development of sport industry, satisfying the spiritual and cultural demands of the people, as well as enhancing the soft power of China.” Liu also suggested that "the focus should start young. Talent should be cultivated through on-campus football activities. The social foundation of the sport of football should be built in order to improve and popularize football in China. ${ }^{40 \text { ", }}$ According to the MOE deputy director, Liu Li-Ming, "GAS and MOE issued The Nationwide Notice for Activating On-campus Youth Football Activities on April $14^{\text {th }}$, 2009, so as to implement the instructions of central leaders. GAS and MOE also co-hosted the initiation ceremony for this program in Qingdao on October $14^{\text {th }}$, 2009. A nationwide workshop for football affairs was held.

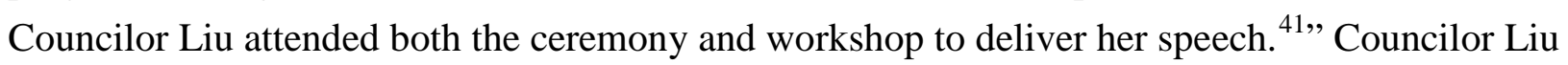
also assembled another key football workshop on January $28^{\text {th }}$, 2011. In addition, GAS director, Liu Peng, the assistant secretary general of State Council, Xiang Zhao-Lun, National Development and Reform commissioners, relevant officials from MOF and MOE, delegates from the corporations, together coaches and players from both the male and female national football teams were all assembled to progress in-depth discussions regarding the development and reform of Chinese football, the establishment of a youth training system, and regulations for professional leagues $^{42}$. This workshop also announced and produced a draft of the official document of Opinions of GAS and MOE on Improving Youth On-campus Football Work ${ }^{43}$ as well as the "500 million in three years" strategic partnership between DWA and CFA ${ }^{44}$.

On July $4^{\text {th }}$, 2011, President Xi greeted guests from South Korea and was presented with a football signed by Park Ji-sung. Meanwhile, Xi publicly announced that his three dreams "are

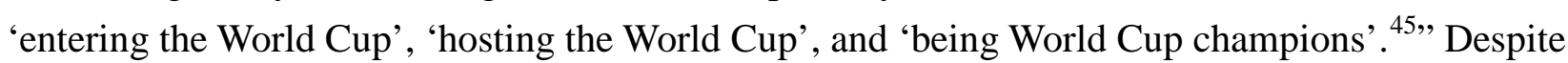
this, Xi's three dreams for football did not improve the development of Chinese football, with 
Chinese national team being well beaten 1-5 by the Thai national team in Hefei on June $15^{\text {th }}, 2013$. The well-known CCTV commentator, He Wei, even described this game as shameful. ${ }^{46}$ According to Chinese scholars, the failure of the Chinese national team exerted a powerful influence on football in China more generally, reinforcing Xi's determination to initiate overall reform ${ }^{47}$. In order to alleviate the dissatisfaction felt by the leader of China, at the $10^{\text {th }}$ CFA assembly held in 2014, the GAS deputy-director and CFA president, Cai Zhen-Hua, declared that "we shall never forget how we lost to the Thai team by 1 to 5 last year...June $15^{\text {th }}$ was a shameful

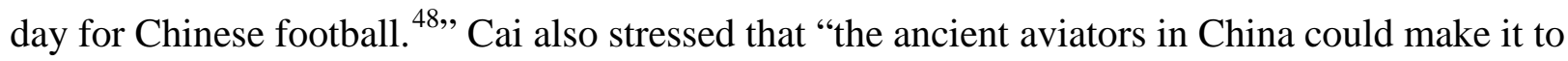
the sky and realize their flying dreams. I thus firmly believe we can fulfill our football dream as well. ${ }^{49, " ~ G A S ~ d i r e c t o r, ~ L i u ~ P e n g ~ a l s o ~ h i g h l i g h t e d ~ X i ' s ~ f o o t b a l l ~ d r e a m s ~ s e v e r a l ~ t i m e s ~ d u r i n g ~ h i s ~}$ speech. He stressed that Liu Yan-dong had hosted many conferences about on-campus youth football and football workshops. Many other significant talks, guides, and orders were also delivered $^{50}$. Furthermore, Liu Peng emphasized that "the Party, State Council, and the public all deeply expect to see the improvement of football. Chinese sports now should use all the resources to the utmost to serve the public as well as to strive for the glory for China. ${ }^{51 \text {, }}$

In addition to the efforts of GAS and CFA, Xi also gradually directed the responsibility of football promotion to the MOE. As an official from the CFA School Football Office noted, "the lottery profits of 5.6 million per year from GAS are definitely not sufficient for the development of on-campus football. Therefore, the well-budgeted and resourced MOE should take the lead in

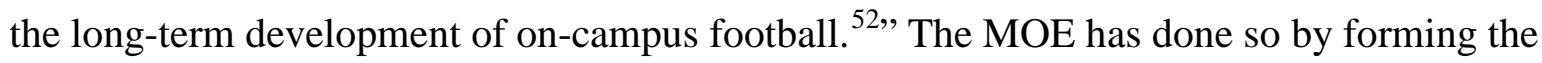
"National Youth Campus Football Leading Group Office (NYLGO)” under the direction of the Party and State Council. The MOE director, Yuan Gui-Ren, served as the leader of NYLGO, with MOE deputy director, Hao Ping, and GAS deputy director, Cai Zheng-Hua, as deputies. The office was set up in the MOE to process daily routines. Wang Deng-Feng, the head of the Physical, Health and Arts Education department of the MOE, serves as the office chief ${ }^{53}$ and was also appointed as the CFA vice-president charged with increasing the impact of the MOE on football ${ }^{54}$.

At a tele-conference concerning on-campus football hosted by councilor of the Politburo and State Council, Liu Yan-Dong, MOE director Yuan explained several points about the promotion of on-campus football, in particular the establishment of around 20,000 football featuring middle and primary schools as well as 200 quality high school football teams nationwide, the construction of around 30 on-campus football trial run regions by 2017, the organization of four level leagues for primary, middle, and high schools as well as universities in accordance with the national on-campus football competition program, and a training project for 6,000 football coaches nationwide by $2015^{55}$. During the meeting, GAS director, Liu Peng, also initiated several important implementation strategies for MOE led on-campus football: 1. To work with the MOE to arrange for the employment of veteran football players, students, and professionals as school coaches; 2. To establish a sound youth league from U9 to U22 and make connections between leagues at different levels; 3. To integrate the resources of GAS and MOE to construct a youth 
football training compound; 4. To provide more access for student football players to the reserved talent pool for the national team, professional football clubs, or to famous overseas clubs ${ }^{56}$.

During an interview with the Xinhua News Agency, Wang Deng-Feng stressed that the leading group was constituted by the MOE, NDRC, SAPPRFT, GAS, and CCCYL, with each agency having its own strengths. The main leaders are the MOE, GAS, and CCCYL whilst the other three agencies provide support for such things as field design, financing, and press releases. "The three main leaders now require an integrated plan and a specific division of labor. For instance, the training of coaches, referees, and teachers requires the efforts of CFA. This is a

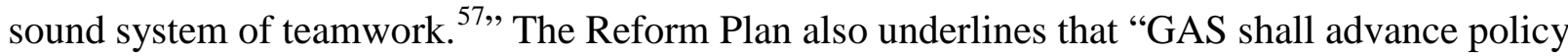
studies and use its leadership to continuously promote the reform and development of football in China, assure the implementation of this plan, and establish the inter-departmental system of football development and reform, while the MOE shall fulfill its responsibilities of supervision over on-campus football activities. ${ }^{58 \text {, }}$

\section{Chinese Leaders Appeal to Corporate Owners to Finance the Chinese Football}

In 1999, the DWG dropped out of the football arena as a result of dissatisfaction with the poor condition of football in China. In 2011, however, the president of DWG, Wang, decided to re-enter the industry with a three-year plan supported by 500 million RMB. Wang was invited to be the consultant for CFA during the $10^{\text {th }}$ CFA convention held on January $21^{\text {st }}, 2014$. He talked about this new position during an interview on CCTV's Dialogue, saying that he would continue to support CFA for three years having been selected as a consultant. He stressed that "it's great to see Xi's passion for football, which will provide important support for Chinese football. People say I am only responding to the call of President Xi, but I think it is actually my honor to be involved. ${ }^{59,}$ As a matter of fact, when he was asked in another interview why he had re-entered the domain of football, Wang calmly explained his three reasons, namely "the leader's direction,

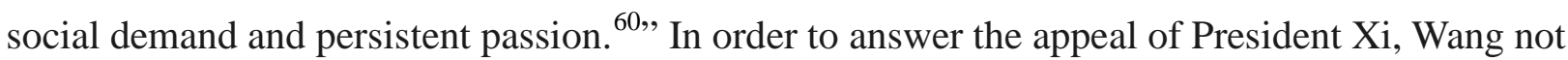
only introduced top coaches and sent out young players to countries excelling in football but also purchased a 20\% share of Club Atlético de Madrid (CAM) for 4.5 million euro, officially becoming one of the shareholders on January $21^{\text {st }}, 2015$. The investment in CAM was mainly to work with the program of "Chinese Youth Football Player in Spain.” From the DWG perspective, Wang indicated that "DWG is glad to contribute to the growth and development of CAM in Asia and would like to learn from their experiences in youth training for developing football in China. ${ }^{61}$ " According to the agreement, CAM would build a youth training center for young Chinese players in Spain. ${ }^{62}$ Wang also mediated with three noted corporations and the management of Infront Sports \& Media (ISM) to successfully merge a 100\% share of stock in ISM with DWG holding $68.2 \%$ of the shares to further help realize Xi's three dreams for Chinese football. At the contract-signing ceremony, Wang suggested that "the merger with ISM would help realize Xi Jin-Ping's World Cup Dreams since the group possess tremendous marketing resources for 
football and on-ice sports ${ }^{63}$." After taking over the business of ISM, since 2016 the DWG has further become a top level sponsor partner of FIFA, which could be an advantage for China's bidding for World Cup events in the future.

Furthermore, the chairperson of EREG, Xu Jia-Yin, also works with RMFC to construct Evergrande Football School and there is also a ten-year plan to expand the cultivation of youth football talents. During those ten years, EREG will donate 100 million to the China Foundation for Poverty Alleviation per annum. Part of this donation will be used to support talented, yet financially disadvantaged, children so that they can have the access to professional football training and coaching. This move is closely related to the preference of president $\mathrm{Xi}$ in relation to football as well as the direction of the Party ${ }^{64}$. In addition, Xu built up the "Evergrande Model" for Chinese football, cultivating football talent to support the national team. Both have had considerable influence on China's football development.

The Chinese leader canvassed the opinions of five stakeholders - the current GAS deputy director and CFA chairperson, Cai Zhen-Hua; FIFA executive committee member and AFC vice-president, Zhang Ji-Long; Mr. Wang from DWG; Mr. Xu from EREG; and the so-called “founding Father of CSL," Lang Xiao-Nong - to prepare the grand blueprint for football development in China. These five stakeholders represent administrative management, industrial management, international organizations, investors, and CSL management respectively ${ }^{65}$. Their views have been more or less documented in the “Reform Plan”. As Wang Jian-Lin stated during his interview on Dialogue on CCTV, "all the major leaders have acknowledged this issue, and therefore we have this football reform conference and the overall reform plan submitted by the State Council. We have found the 'right medicine' to bring life back to Chinese football, namely the "Reform Plan" proposed by the Party leaders. ${ }^{66 ”, ~ A s ~ a ~ m a t t e r ~ o f ~ f a c t, ~ t h e ~ n i g h t ~ b e f o r e ~ a ~ v i s i t ~ t o ~}$ the United Kingdom, Xi assigned Liu Yan-Dong to attend the China-UK Football Development Forum in order to arrange exchange and cooperation on football with UK. This was un surprising and indeed the current GAS deputy director and the CFA chairperson, Cai Zhen-Hua, Mr. Wang from DWG and Mr. Xu from EREG also attended the meeting ${ }^{67}$. From this, we can tell much about the Chinese government's appreciation of Mr. Wang and $\mathrm{Mr}$. Xu, along with its ambition to reinvigorate and promote Chinese football to the world through resources provided by enterprises.

\section{Conclusion}

The developing strategies for elite football in China have been closely associated with the objectives of the Chinese leader, Xi Jin-Ping, in the wake of the 2008 Beijing Olympics. The focus of these strategies, managed by the chief of CFMC, GAS, has now been upgraded to be handled by State Councilor, Liu Yan-Dong ${ }^{68}$. Due to the fact that elite football development involves various factors and aspects and is therefore complicated, and that the enormous amount of expense is unaffordable for the CFMC, the State Council has gradually taken over the responsibility to coordinate relevant departments and acquire more resources from private 
corporations and local governments, and, in time, to save elite football in China. With regard to China's management of a series of corruption scandals in football, the State Council has called its seven departments together and set up the CEDCNFL. The State Council also pledges to give the CFA more autonomy to allow professionals to build a system consistent with elite football development. Indeed, the State Council put forward the idea of the "separation of government and football associations” in practice, so as to reduce the conflict of interests between the CFMC and professional football clubs. In addition, in response to the problem of a lack of football talent, aside from putting an emphasis on the importance of football at National Games, China is also dedicated to youth on-campus football, having the MOE replace the School Football Office in the CFA to lead the development of on-campus football. In order to gain more resources, senior officials in the State Council of China directly turned to the private corporations for patronage. These corporations have also cooperated with football clubs in Europe and South America so that the "inviting in and sending out" policy could be reinforced. Moreover, the State Council published two official documents, namely "Several Opinions of the State Council of the People's Republic of China, on Accelerating the Development of Sports Industry to Promote the Sport Consumption" and the "Overall Reform Plan to Boost the Development of Football in China" in 2014 and 2015 respectively. Football has thus become the bellwether sport for the sports industry development in China.

As for power relations, the stakeholders involved are government officials and owners of private enterprises. In addition to Xi Jin-Ping, government officials include members of the State Council, MOE, GAS, NDRC, MOF, the CFA, local sports bureaus and local football federations. As for the entrepreneurs, Wang from DWG and Xu from EREG have been the most influential actors. However, the private enterprises have responded to the preferences of government. Wang has sponsored the CFA, especially by introducing top trainers and sending out young players to countries excelling in football. Xu also built up the "Evergrande model" for Chinese football, cultivating football reserved talents to support the national team. Both Wang and Xu have had a major influence on China's football development.

Viewed from the perspective of the model of state corporatism, the development of Chinese football after the 2008 Beijing Olympic Games has been dominated by the government and, in particular, the leader of the country, Xi Jing-Ping. The goals set by the government for Chinese football were also based on Xi's three World Cup dreams. As a consequence, in order to accomplish Xi's “World Cup Dreams”, the sport system, the education system and even the industrial sector appear to have come to regard raising the level of elite football in China as an important task. However, those three systems also have conflicts of interest in reality and this is a crucial issue that cannot be ignored in relation to the future development of Chinese football. Last but not the least, the "Party group" at all levels of the football associations in China, has played and will continue to play a key role in governing the development of the Chinese football ${ }^{69}$. 
${ }^{1}$ Schmitter, P. C. and Lehmbruch, G., eds, Trends toward Corporatist Intermediation (CA: SAGE, 1979).

2 Malloy, J. M., 'Authoritarianism and Corporatism in Latin America' (Pittsburgh: University of Pittsburgh Press, 1977).; Wiarda, H. J., 'Corporatism and National Development In Latin America’ (Colorado: Westview Press, 1981).

3 Schmitter, P. C., 'Still the Century of Corporatism?' Review of Politics 36, (1974): 85-131.

${ }^{4}$ Howard J. Wiarda, ed, New Directions in Comparative Politics (3rd Ed.) (Colorado: Westview Press, 2002).

${ }^{5}$ Anthonsen, M., Lindvall, J., and Schmidt-Hansen, U., 'Social democrats, unions and corporatism: Denmark and Sweden compared', Party Politics 17 no. 1, (2011): 118-134.; Heemskerk, E., Mokken, R., and Fennema, M., 'The fading of the state: Corporate-government networks in the Netherlands', International Journal Of Comparative Sociology, 53 no. 4, (2012): 253-274.; Rolland, A., 'Reviewing Social Democratic Corporatism: Differentiation Theory and the Norwegian Labor Press', Communication Review 11, no. 2, (2008): 133-150.

${ }^{6}$ Schmitter, 'Still the century of corporatism?'.

7 Lee, J., 'A Comparative Analysis of Corporatist Policymaking Coordination in Japan and Korea', Korean Social Science Journal 33, no. 1, (2004): 61-88.; Shen, Tzong-Ruey, 'The Transformation of Functions on the Labor Union in Taiwan', Journal of Culture and Society 12, (2001): 159-187.; Huang, Tzu-Ting, 'The Characteristic of Singapore's Social Welfare Policy: State and Social Groups under State-Corporatism', Review of Global Politics 20, (2007): 111-150.

${ }^{8}$ White, G., 'Chinese Trade Unions in the Transition from Socialism: Towards Corporatism or Civil Society?’ British Journal of Industrial Relations 34, no. 3, (1996): 433-457.; Scapens, R. W., and Yang, C. L., 'Chinese Public Finance Framework: A Critical Analysis', Financial Accountability \& Management 26, no. 2, (2010): 163-189.; Unger, J., 'Chinese Associations, Civil Society, and State Corporatism: Disputed Terrain', in J. Unger (Ed.), Associations and the Chinese State: Contested Spaces. (New York: ME Sharpe Inc, 2008), 1-13.; Unger, J., and Chan, A., 'China, Corporatism, and the East Asian Model', The Australian Journal of Chinese Affairs, 33, (1995): 29-53. Wang, Hsin-Hsien, 'Bringing Society Back in? A Theoretical Review on the Rise of Intermediary Organizations in China', Journal of Social Sciences and Philosophy 18, no. 2, (2006): 293-326.; Liu, Wei-Ming, 'Corporatism and the New Perspective on China's political transformation', Theory and Reform, 4, (2005): 5-8.

${ }^{9}$ Solinger, D. J., 'Urban Entrepreneurs and the State: The Merger of State and Society', in A. L. Rosenbaum (ed.), State and Society in China: The Consequences of Reform. (Colorado: Westview Press, 1992), 121-141.

${ }^{10}$ Liu, Qian, 'Corporatism and Chinese studies: a literary survey', Chinese Social Science Quarterly, 2, (2009), 75-93.

${ }^{11}$ Sun, Pei-Dong, 'Civil Society or Corporatism: Review of Studies on Emerge of Economic Community and the Transformation of the Relationship between State and Society', Social Sciences in Guangdong, 5, (2011), 218-224.

${ }^{12}$ This is according to the vice director of Sports Ethics and Integrity Risk Research Center, Beijing Sports University, interviewed on 18 January 2014.

${ }^{13}$ Chang, Jian, 'The $10^{\text {th }}$ CFA convention Documents- The $10^{\text {th }}$ CFA convention Work Report' (Beijing: Chinese Football Association, 2014), 26.

9 This is according to one of the senior staff members in charge of the financial affairs of the CFA, interviewed on 22 January 2014.

14 This is according to one of the senior staff members in the GAS, interviewed on 13 January 2015.

15 This is according to a former official A from CFA School Football Office, interviewed on 4 January 2014.

${ }^{16}$ This is according to an official B from CFA School Football Office, interviewed on 15 January 2014.

${ }^{17}$ Ministry of Education, PRC, 'Notice from the Ministry of Education on Forming "National On-campus Youth Football Leading Group”', (2015), http://www.moe.edu.cn/publicfiles/business/htmlfiles/moe/s5972/201501/183357.html (accessed 16 January 2015).

${ }^{18}$ Liu, Peng, 'Talks from Director Liu Peng on National Sports Bureaus Assembling (full text)', (2011), http://www.sport.gov.cn/n16/n1077/n1392/n2590312/n2590332/2635182.html (accessed 16 January 2015).

19 This is according to official from Athletic Sport Department, GAS, interviewed on 21 January 2014.

${ }^{20}$ Wang, Jing-Yu and Li, Zheng, 'Exclusive Interview with Xiao Tien: 'One Champion Three Medals' Works on Boosting football in China’, (2013), http://news.xinhuanet.com/sports/2013-09/12/c_125377062.htm (accessed 16 January 2013).

${ }^{21}$ General Office of the State Council of PRC, 'Overall Reform Plan to Boost the Development of Football in China', (2015), http://www.sport.gov.cn/n16/n1077/n1227/6255814.html (accessed 16 January 2015).; China Interactive Sports Technology Invention, 'Mr. Xi and Chinese Football Back in the Years' (2015), http://politics.sports.cn/yw/2015/0228/91110.html (accessed 16 January 2015).

${ }^{22}$ Gong, Bin and Wang, Yong, 'Exclusive Interview with Wang Deng-Fong: Construct New Football Schools in the in the football-featured school system', (2015), http://news.xinhuanet.com/sports/2015-03/04/c_127543708.htm (accessed 16 January 2015).

${ }^{23}$ General Office of the State Council of PRC, 'Overall Reform Plan to Boost the Development of Football in China'; China Interactive Sports Technology Invention, 'Mr. Xi and Chinese Football Back in the Years', (2015), http://politics.sports.cn/yw/2015/0228/91110.html (accessed 17 January 2015). 
${ }^{24}$ Sina Sport, ‘Shi Xue Ching Talls: Wanda Select Youths for Free Study in Spain’, (2011),

http://sports.sina.com.cn/j/2011-12-20/11175876137.shtml (accessed 17 January 2015).

${ }^{25}$ Ma, Xiang-Fei, 'Liu Peng: CFA Management and Operation Combined System Would Prolong the Reform of Football in China’, (2010), http://www.chinadaily.com.cn/typd/2010-09/28/content_11356810.htm (accessed 17 January 2015).

${ }^{26}$ This is according to one of the senior staff of the CFA, interviewed on 15 January 2015.

${ }^{27}$ General Office of the State Council of PRC, 'Overall Reform Plan to Boost the Development of Football in China'; China Interactive Sports Technology Invention, 'Mr. Xi and Chinese Football Back in the Years', (2015), http://politics.sports.cn/yw/2015/0228/91110.html (accessed 17 January 2015)

${ }^{28}$ Cai, Zheng-Hua, 'Separation CFA from Administration Doesn't Equal to Ease on the Political Leading and Management’, (2015), http://news.xinhuanet.com/sports/2015-03/16/c_127586695.htm (accessed 19 March 2015).

${ }^{29}$ Ibid.

${ }^{30}$ Ibid.

${ }^{31}$ General Office of the State Council of PRC, 'Overall Reform Plan to Boost the Development of Football in China'; China Interactive Sports Technology Invention, 'Mr. Xi and Chinese Football Back in the Years', (2015), http://politics.sports.cn/yw/2015/0228/91110.html (accessed 20 March 2015).

${ }^{32}$ State Council, PRC, 'Several Opinions of the State Council of the People's Republic of China, on Accelerating the Development of Sports Industry to Promote the Sport Consumption', (2014), http://www.gov.cn/zhengce/content/2014-10/20/content_9152.htm (accessed 20 January 2015).

33 Xinhua News, 'Deputy of Economic Department of GAS Considers the "Opinions” as Highly Valuable and Practicable’, (2014), http://www.sport.gov.cn/n16/n1077/n1227/5828703.html (accessed 20 January 2015).

${ }^{34}$ Ibid.

${ }^{35}$ Li, Xiang, ‘Chinese Leaders and Football: Xi Jin-Ping Wish for Winning the World Cup Champion', (2012), http://cnsoccer.titan24.com/2012-12-26/195942_4.html (accessed 20 January 2013).

${ }^{36}$ Xinhua News, 'Xi Jin-Ping’s Three Dreams of Football: Hosting and Winning World Cup’, (2013), http://news.xinhuanet.com/sports/2013-06/06/c_124819008.htm (accessed 20 January 2015).

${ }^{37}$ Sheng, Hui; Liu, Zao; Wang, Fei-Fei; and Tang, Qian-Er, 'Xi Jin-Ping: Mr. Football at the Diplomatic Arena', (2014), http://politics.people.com.cn/BIG5/n/2014/0330/c1024-24772409.html (accessed 6 January 2015).

${ }^{38}$ This is according to a professor from Beijing Sport University, interviewed on 1 July 2014.

${ }^{39} \mathrm{Lu}$, Yen, 'The Recent Concerns Expressed by Chinese Officials are Worth for Notice', (2009), http://www.chi nanews.com/ty/ty-gnzq/news/2009/10-15/1912040.shtml (accessed 6 January 2015).

${ }^{40}$ Liu, Yan-Dong, 'Liu Yan-Dong: Find the Crux of Problem and Advance the Development of Football in China', (2009), http://www.chinanews.com/ty/news/2009/10-15/1911147.shtml (accessed 6 January 2015).

${ }^{41}$ Liu, Li-Ming, 'Ministry of Education Deputy: Advance the Comprehension and Mechanism of On-campus Football', (2010), http://sports.qq.com/a/20101227/000736.htm (accessed 6 January 2015).

${ }^{42}$ This is according to an assistant for deputy director at General Administration of Sport, interviewed on 15 July 2014.

${ }^{43}$ General Administration of Sports and Ministry of Education, 'Opinions of GAS and MOE on improve youth on-campus football work’, (2012), http://www.wanda.cn/2011/2011_0130/4784.html (accessed 6 January 2015).

${ }^{44}$ Shi, Shue-Ching and Lu, Hai-Yang, 'President Wang Jian-Lin Participates in Football Work Conference', http://sports.sina.com.cn/c/2011-07-06/11285646169.shtml (accessed 6 January 2015).

45 Sina News, 'Xi Jin-Ping proposed three wishes for Chinese Football: Participating, Hosting, and Winning World Cup', (2011), http://hunan.voc.com.cn/article/201306/201306161513127169.html (accessed 6 January 2015).

${ }^{46}$ Kuo, Cheng, 'National Team Dreadfully Lost to Thai Team by 1:5: Forced to Facing the Facts of Chinese Football', (2013), http://hunan.voc.com.cn/article/201306/201306161513127169.html (accessed 6 January 2015).

47 This is according to a professor from Beijing Sport University, interviewed on 1 July 2014.

${ }^{48}$ Cai Zhen-Hua, 'The $10^{\text {th }}$ CFA convention Documents - The Talk on CFA convention' (Beijing: Chinese Football Association, 2014, 13).

${ }^{49}$ Ibid., 20.

${ }^{50}$ Liu, Peng, 'The $10^{\text {th }}$ CFA convention Documents - The Talk on CFA convention', (Beijing: Chinese Football Association, 2014, 2).

${ }^{51}$ Ibid., 9-10.

${ }^{52}$ This is according to an official B from CFA School Football Office, interviewed on 15 January 2014.

${ }^{53}$ Ministry of Education, PRC, 'Notice from the Ministry of Education on Forming "National On-campus Youth Football Leading Group”', (2015), http://www.moe.edu.cn/publicfiles/business/htmlfiles/moe/s5972/201501/183357.html (accessed 6 January 2015).

${ }^{54}$ Chinese Football Association, 'The $10^{\text {th }}$ CFA convention Documents - the list for $10^{\text {th }}$ CFA authorities', (Beijing: Chinese Football Association, 2014, 76). 
${ }^{55}$ Yuan, Kuei-Ren, 'Effective Approaches to Promote and Lead to Breakthrough of On-campus Football', (2014), http://www.moe.edu.cn/publicfiles/business/htmlfiles/moe/moe_797/201412/179080.html (accessed 6 January 2015).

${ }^{56}$ Liu, Peng, 'Summary on the Talks regarding National Youth On-campus Football Works: Improve Professional Instructions and Establish Reserved Talents Cultivation System', (2014), http://www.moe.edu.cn/publicfiles/business/htmlfiles/moe/moe_797/201412/179080.html (accessed 6 January 2015).

${ }^{57}$ Gong, Bin and Wang, Yong, 'Exclusive Interview with Wang Deng-Fong: Construct New Football Schools in the in the football-featured school system', (2015), http://news.xinhuanet.com/sports/2015-03/04/c_127543708.htm (accessed 6 July 2015).

${ }^{58}$ General Office of the State Council of PRC, 'Overall Reform Plan to Boost the Development of Football in China'.

${ }^{59}$ CCTV, 'Dialogue' Football in China: Analysis of the Current Status and Future of Football Reform', (2015), http://jingji.cntv.cn/2015/03/18/ARTI1426648722161960.shtml (accessed 6 July 2015).

${ }^{60}$ Sun, Yu-Xuan, 'Game of Power: Uncover the Veil of Football Power Figure, Wang Jian-Lin’, (2015), http://sports.qq.com/a/20150213/045959.htm (accessed 6 July 2015).

${ }^{61}$ Xinhua News, 'Wanda Group Purchases 20\% stock and Officially Becomes the Stockholder of Royal Madrid Football Club’, (2015), http://industry.sports.cn/news/others/2015/0401/96115.html (accessed 6 July 2015).

${ }^{62}$ Xiao, Nan, 'Wang Jian-Lin Purchases 20\% Stock of Royal Madrid Football Club. A One Stone Two Birds Move’, (2015), http://sports.people.com.cn/n/2015/0121/c22176-26422836.html (accessed 6 July 2015).

${ }^{63}$ Gong, Bin; Wang, Yong; and Yue, Dong-Xin, 'Wang Jian-Lin: Merge of Ifot Group will Speed up the Application for Hosting World Cup’, (2015), http://news.xinhuanet.com/sports/2015-02/10/c_127480519.htm (accessed 6 July 2015).

${ }^{64}$ This is according to the secretary of the chairman of the CFA, interviewed on 13 January 2015.

65 Jia, Lei-Shi, 'Central Government Consults Five Stakeholders Including Cai Jeng-Hua, Xu Jia-Yin, and Wang Jian-Lin for Football Development’, (2014), http://sports.sina.com.cn/c/2014-09-29/07427351745.shtml (accessed 6 July 2015).

${ }^{66}$ CCTV, “'Dialogue” Football in China'.

${ }^{67}$ Zhang, Chunyan and Ma, Chi, 'London forum advances soccer hopes', (2015), http://europe.chinadaily.com.cn/world/2015-09/18/content_21920790.htm (accessed 6 July 2015).

${ }^{68}$ CCTV, 'Vice premier to lead football reform team', (2015), http://english.cntv.cn/2015/05/01/VIDE1430428922901855.shtml (accessed 6 July 2015).

${ }^{69}$ See also Chen, Yu-Wen., Tan, Tien-Chin and Lee, Ping-Chao., 'The Chinese Government and the Globalization of Table Tennis: A Case Study in Local Responses to Sports Globalization', The International Journal of the History of Sport 32, no. 10, (2015):1336-1348. ; Tan, Tien-Chin., 'Assessing the Sociology of Sport: On Globalisation and Sport Policy’, International Review for Sociology of Sport 50, no. 4-5, (2015): 612-616.; Tan, Tien-Chin and Bairner, Alan., 'Globalisation and Chinese Sport Policy: The case of the Elite Football in the People's Republic of China', The China Quarterly,203, September, (2010): 581-600. 